\title{
Frequency and distribution of winter melt events from passive microwave satellite data in the pan-Arctic, 1988-2013
}

\author{
Libo Wang ${ }^{1}$, Peter Toose ${ }^{1}$, Ross Brown ${ }^{2}$, and Chris Derksen ${ }^{1}$ \\ ${ }^{1}$ Climate Processes Section, Climate Research Division, Environment and Climate Change Canada, Toronto, Ontario, Canada \\ ${ }^{2}$ Climate Processes Section, Climate Research Division, Environment and Climate Change Canada@Ouranos, Montreal, \\ Québec, Canada
}

Correspondence to: Libo Wang (libo.wang@canada.ca)

Received: 19 May 2016 - Published in The Cryosphere Discuss.: 17 June 2016

Revised: 19 September 2016 - Accepted: 28 September 2016 - Published: 3 November 2016

\begin{abstract}
This study presents an algorithm for detecting winter melt events in seasonal snow cover based on temporal variations in the brightness temperature difference between 19 and $37 \mathrm{GHz}$ from satellite passive microwave measurements. An advantage of the passive microwave approach is that it is based on the physical presence of liquid water in the snowpack, which may not be the case with melt events inferred from surface air temperature data. The algorithm is validated using in situ observations from weather stations, snow pit measurements, and a surface-based passive microwave radiometer. The validation results indicate the algorithm has a high success rate for melt durations lasting multiple hours/days and where the melt event is preceded by warm air temperatures. The algorithm does not reliably identify short-duration events or events that occur immediately after or before periods with extremely cold air temperatures due to the thermal inertia of the snowpack and/or overpass and resolution limitations of the satellite data. The results of running the algorithm over the pan-Arctic region (north of $50^{\circ} \mathrm{N}$ ) for the 1988-2013 period show that winter melt events are relatively rare, totaling less than 1 week per winter over most areas, with higher numbers of melt days (around two weeks per winter) occurring in more temperate regions of the Arctic (e.g., central Québec and Labrador, southern Alaska and Scandinavia). The observed spatial pattern is similar to winter melt events inferred with surface air temperatures from the ERA-Interim (ERA-I) and Modern Era-Retrospective Analysis for Research and Applications (MERRA) reanalysis datasets. There was little evidence of trends in winter melt event frequency over 1988-2013 with the exception of negative trends over northern Europe at-
\end{abstract}

tributed to a shortening of the duration of the winter period. The frequency of winter melt events is shown to be strongly correlated to the duration of winter period. This must be taken into account when analyzing trends to avoid generating false positive trends from shifts in the timing of the snow cover season.

\section{Introduction}

Snow cover is important in Arctic climate and ecological systems and has decreased in areal extent and duration especially during the spring period in response to rapid Arctic warming in recent decades (Brown and Robinson, 2011; Callaghan et al., 2011; Derksen and Brown, 2012). The conventional wisdom is that Arctic warming will result in an increase in the frequency and duration of winter melt events, which may also include rain-on-snow (ROS) events. These winter melt-refreeze events modify the physical properties of snow (albedo, density, grain size, thermal conductivity), generate winter runoff (Bulygina et al., 2010; Johansson et al., 2011) and can result in potentially significant impacts on the surface energy budget, hydrology and soil thermal regime (Boon et al., 2003; Hay and McCabe, 2010; Rennert et al., 2009). The refreezing of melt water can also create ice layers that adversely impact the ability of ungulate travel and foraging (Hansen et al., 2011; Grenfell and Putkonen, 2008), and exert uncertainties in snow mass retrieval from passive microwave satellite data (Derksen et al., 2014; Rees et al., 2010). Winter warming and melt events may also damage shrub species and tree roots, affecting plant phenology and 
reproduction in the Arctic (AMAP, 2011; Bokhorst et al., 2009).

Winter melt events are rare extreme events over most of the Arctic and are sporadic in time and space (Pedersen et al., 2015). These events are linked to intrusion of warm air from southerly or southwesterly flow; may be associated with fog (Semmens et al., 2013), rain and/or freezing rain; and typically last for several days. Previous studies (Cohen et al., 2015; Rennert et al., 2009) have shown that the synoptic conditions associated with these events are closely related to larger modes of atmospheric circulation.

Microwave remote sensing measurements are very sensitive to the presence of liquid water in snow. Dry snow is a mixture of air and ice. Because the permittivity of water is much higher than air and ice at microwave frequencies, the introduction of even a small amount of liquid water $(0.5 \%)$ in snow can increase the permittivity of snow by over an order of magnitude (Ulaby et al., 1986). This increases absorption and reduces the penetration depth, which in turn results in a large increase in brightness temperature $\left(T_{\mathrm{B}}\right)$ and decrease in radar backscatter. Satellite active and passive microwave measurements have been widely used for snowmelt detection over various components of the Arctic cryosphere during the spring melt period (e.g., Kim et al., 2011; Markus et al., 2009; Tedesco, 2007; Wang et al., 2011). Only a few satellite studies have focused on winter melt or ROS detection, and are mainly for specific regions or limited time periods (Bartsch, 2010; Bartsch et al., 2010; Dolant et al., 2016; Grenfell and Putkonen, 2008; Semmens et al., 2013; Wilson et al., 2013). Here we develop an algorithm to detect winter melt from satellite passive microwave (PMW) data over panArctic snow-covered land areas north of $50^{\circ} \mathrm{N}$ for the period 1988-2013.

Winter melt and ROS events can also be inferred from surface weather observations (Groisman et al., 2003; McBean et al., 2005; Pedersen et al., 2015), reanalyses (Cohen et al., 2015; Rennert et al., 2009), or reanalysis-driven snowpack models (Liston and Hiemstra, 2011). In most of these studies, winter melt events are assumed to occur when the daily surface air temperature exceeds a certain threshold. For example, Groisman et al. (2003) defined a thaw day as a day with snow on the ground when the daily mean surface air temperature is above $-2{ }^{\circ} \mathrm{C}$. Inferring thaw events from surface air temperatures in this way does not consider the energy balance of the snowpack. In addition, reanalysis datasets can contain important biases and inhomogeneities over the Arctic (e.g., Rapaic et al., 2015) that will impact the spatial and temporal frequency of the inferred winter thaw events. The advantage of the passive microwave approach described above is that melt events are directly linked to the appearance of liquid water in snow which drives changes in snowpack properties relevant to Arctic ecosystems. The brightness temperature time series is also considered to be consistent over the 1988-2013 period as it is derived from near-identical spaceborne sensors.
Table 1. Data periods for the different satellite passive microwave radiometers used for melt detection in this study.

\begin{tabular}{llll}
\hline Satellite & Start date & End date & Overpass a.m./p.m. \\
\hline F-08 SSM/I & Jul 1988 & Dec 1991 & Ascending/descending \\
F-11 SSM/I & Jan 1992 & May 1995 & Descending/ascending \\
F-13 SSM/I & May 1995 & Dec 2008 & Descending/ascending \\
F-17 SSMIS & Jan 2009 & present & Descending/ascending \\
\hline
\end{tabular}

Previous studies have linked field observations of ice layer formation from ROS events with satellite measurements (Bartsch et al., 2010; Grenfell and Putkonen, 2008), but few studies have showed links between satellite measurements and in situ observations of changes in snow properties from melt-refreeze events (Langlois et al., 2012; Nghiem et al., 2014). Passive microwave satellite data have two important limitations for detecting melt-refreeze events: the relatively coarse resolution $(10-25 \mathrm{~km})$ and the twice-daily overpasses. Thus, melt events of short duration or limited spatial distribution may not be detectable. The objectives of this study are to (1) develop an algorithm for winter melt detection from PMW data and (2) to characterize winter melt events detectable by PMW at the satellite scale using weather station observations, surface-based PMW radiometer measurements, and snow pit surveys observed during multiple field campaigns. These PMW results are compared to winter melt detection results inferred from near surface air temperature fields from two commonly used reanalysis datasets. Trends in PMW-derived winter melt frequency over the period 19882013 are presented along with a demonstration of the impact on trend results of using a fixed winter period for defining the snow season.

\section{Data and methods}

\subsection{Satellite passive microwave data}

This study uses $T_{\mathrm{B}}$ data from the Special Sensor Microwave/Imager (SSM/I, 1987-2008), and the Special Sensor Microwave Imager/Sounder (SSMIS, 2009 to present) re-projected to $25 \mathrm{~km}$ equal-area scalable earth-grid (EASEGrid) available from the National Snow and Ice Data Center in Boulder, Colorado (Armstrong et al., 1994). These sensors provide a continuous time series of $T_{\mathrm{B}}$ since 1987 (Table 1). We do not perform sensor cross calibration given that only small differences were found between sensors (Abdalati et al., 1995; Cavalieri et al., 2012; Stroeve et al., 1998). Since our melt detection algorithm (described below) only uses the relative change in the temporal variations in $T_{\mathrm{B}}$, slight offsets in absolute $T_{\mathrm{B}}$ between sensors should not affect algorithm performance. The gaps in the data are filled by linear interpolation from adjacent days. Vertically polarized $T_{\mathrm{B}}$ from both morning and afternoon overpasses are utilized to increase the 


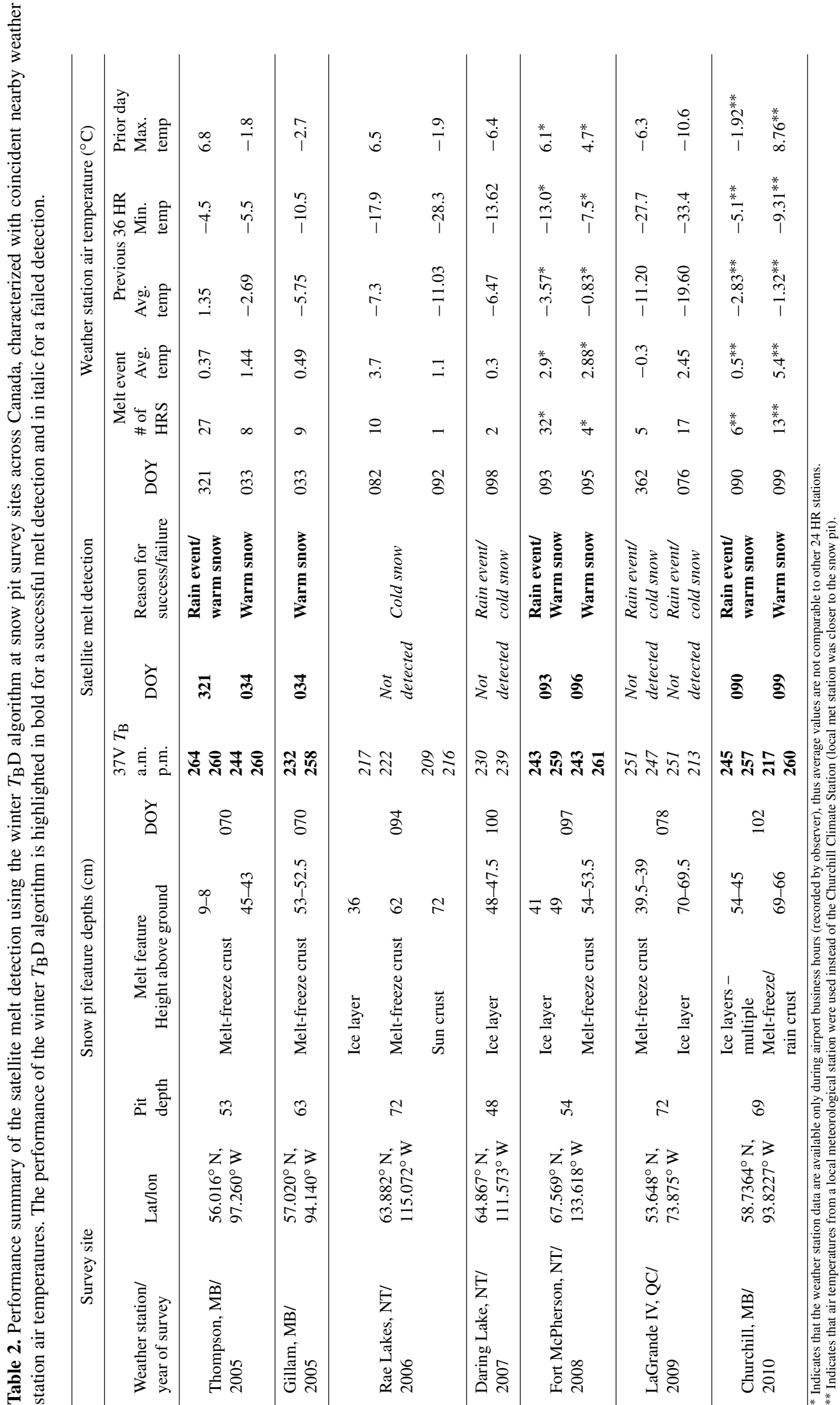




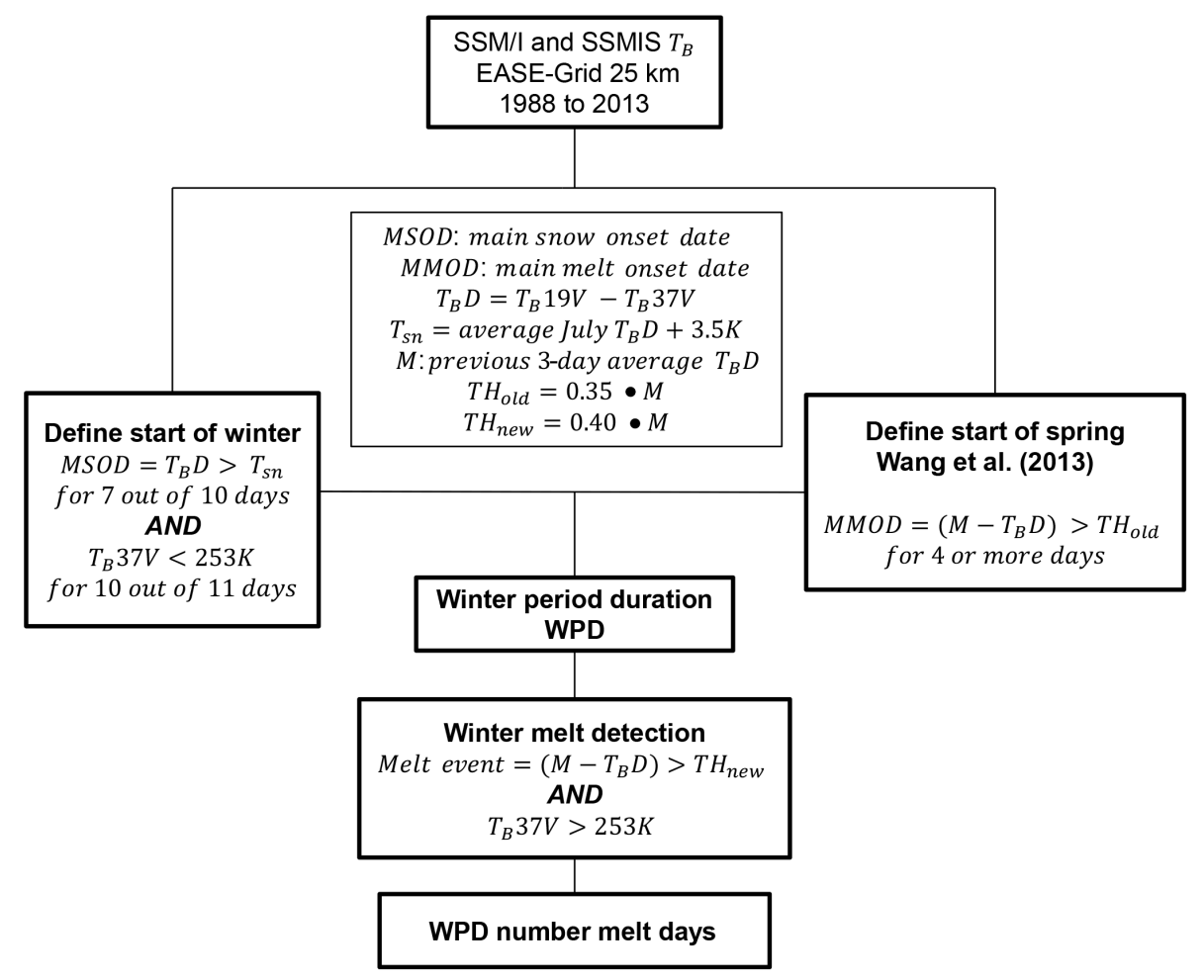

Figure 1. Schematic flow chart of the winter $T_{\mathrm{B}} \mathrm{D}$ melt detection method for PMW satellite data.

likelihood of observing melt events. Due to large temporal gaps in the early SSM/I record, the time series used begin in the fall of 1988 and extend to 2014 (Table 1). Although horizontal polarized measurements are more sensitive to ice lenses within the snowpack (Derksen et al., 2009; Rees et al., 2010), there is not much difference between the two polarizations for melt detection and we use vertically polarized measurements to be consistent with Wang et al. (2013).

\subsection{Winter melt detection method for PMW}

As the purpose of this study is to detect winter melt events, the winter period duration (WPD) is defined as occurring between the main snow onset date (MSOD) in the fall (beginning of continuous dry snow cover on the ground) and the main melt onset date (MMOD) in the spring (i.e., the beginning of the period with frequent melt-refreeze diurnal cycles) at each pixel. Figure 1 illustrates the steps involved in detecting melt events for the WPD, based on the temporal variations in the difference of the brightness temperature $\left(T_{\mathrm{B}} \mathrm{D}\right)$ between 19 and $37 \mathrm{GHz}$ and a $37 \mathrm{GHz} T_{\mathrm{B}}$ threshold. For dry snow conditions, as snow accumulates $T_{\mathrm{B}} \mathrm{D}$ increases due to the larger scattering effect of the microwave signal by snow grains at 37 vs. $19 \mathrm{GHz}$ (Chang et al., 1987). Upon the appearance of liquid water in snow, $T_{\mathrm{B}}$ increases at both frequencies and results in a sharp drop in $T_{\mathrm{B}} \mathrm{D}$ to similar magnitudes seen in snow-free conditions, but will quickly revert back to dry snow $T_{\mathrm{B}} \mathrm{D}$ levels once the snow refreezes, allowing for the detection of melt-refreeze events (Fig. 2).

The purpose of determining MSOD is to capture the earliest start date of the continuous dry snowpack. The MSOD is determined as the first date when (1) $T_{\mathrm{B}} \mathrm{D} \geq \mathrm{Tsn}$ (a threshold = mean July $T_{\mathrm{B}} \mathrm{D}+3.5 \mathrm{~K}$ ) for 7 out of 10 days and (2) $T_{\mathrm{B}} 37 \mathrm{v}<253 \mathrm{~K}$ for 10 out of 11 days (Fig. 1 ). The thresholds and conditions were optimized by comparing the PMW determined MSOD to daily snow depth observations from the Global Surface Summary of the Day dataset archived at the National Climate Data Center (http://www.ncdc.noaa. gov). The $T_{\mathrm{B}}$ criterion in (2) is applied to exclude periods with $T_{\mathrm{B}} \mathrm{D}$ fluctuations related to early season freeze/thaw cycles rather than winter melt events (see below for its derivation).

MMOD is determined following Wang et al. (2013). Their algorithm was based on temporal variations in $T_{\mathrm{B}} \mathrm{D}$ relative to the previous 3-day average $T_{\mathrm{B}} \mathrm{D}$ (referred to as $M$ hereafter). Melt onset was detected if the difference in $M$ and daily $T_{\mathrm{B}} \mathrm{D}$ was greater than a threshold $\left(\mathrm{TH}_{\mathrm{old}}=0.35 \cdot M\right)$ for four or more consecutive days. Based on trial and error, the MMOD detection algorithm in Wang et al (2013) is modified here to detect mid-winter melt events that are typically of shorter duration. Firstly, the threshold is modified slightly from $\mathrm{TH}_{\mathrm{old}}=0.35 \cdot M$ to $\mathrm{TH}_{\text {new }}=0.4 \cdot M$ (pixel-dependent) since the goal is to detect melt events with one or more days of duration (instead of four or more days as in the previous 


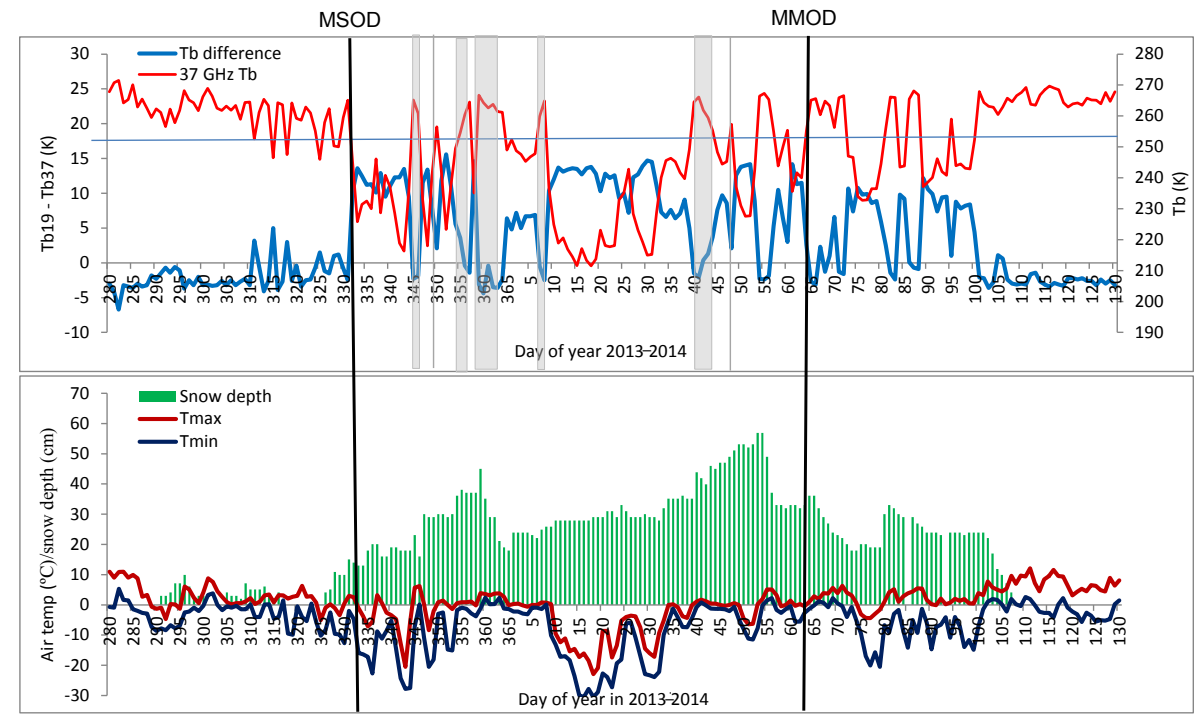

Figure 2. Example of time series of SSM/I $T_{\mathrm{B}} \mathrm{D}$ (a) and daily surface air temperature $\left({ }^{\circ} \mathrm{C}\right) /$ snow depth (cm) (b) at Pudasjarvi, Finland $\left(65.4^{\circ} \mathrm{N}, 26.97^{\circ} \mathrm{E}\right)$ during the 2013-2014 winter. The vertical grey lines/bars in (a) represent melt events detected by satellite.

study), and secondly, a $T_{\mathrm{B}} 37 \mathrm{v}$ threshold condition is added following Semmens et al. (2013) to mitigate false detection due to $T_{\mathrm{B}} \mathrm{D}$ changes not related to melt (e.g., from noise or artifacts from data gap filling). The resulting expression for winter melt event conditions is $\left(M-T_{\mathrm{B}} \mathrm{D}\right)>\mathrm{TH}_{\text {new }}$ and $T_{\mathrm{B}} 37 \mathrm{v} \geq 253 \mathrm{~K}$ for one day (Fig. 1), referred to as the winter $T_{\mathrm{B}} \mathrm{D}$ algorithm hereafter. The $T_{\mathrm{B}} 37 \mathrm{v} \geq 253 \mathrm{~K}$ condition was obtained by evaluating a range of $T_{\mathrm{B}} 37 \mathrm{v}$ values from 250 to $255 \mathrm{~K}$, at $1 \mathrm{~K}$ increments to identify the threshold most sensitive to the presence/absence of liquid water in snow. This was inferred from histograms of daily maximum $\left(T_{\max }\right)$, mean $\left(T_{\mathrm{m}}\right)$, and minimum $\left(T_{\min }\right)$ air temperatures for days detected as melting at all available weather stations during 20002007 (see locations in Fig. 5b, $\sim 5100$ observations in total). The results show that for $T_{\mathrm{B}} 37 \mathrm{v}=253 \mathrm{~K}, T_{\max }$ is $\geq 0{ }^{\circ} \mathrm{C}$ for nearly $96 \%$ of cases, $T_{\min }$ is $<0^{\circ} \mathrm{C}$ for $94 \%$, and $T_{\mathrm{m}}$ is $\geq 0{ }^{\circ} \mathrm{C}$ for $80 \%$. This suggests that the PMW-detected winter melt events are consistent with diurnal positive air temperature events, while most of the events $(80 \%)$ probably last multiple hours, thus corresponding to days with $T_{\mathrm{m}} \geq 0{ }^{\circ} \mathrm{C}$. If a melt event is detected within 10 days of the MMOD, then it is not considered a mid-winter melt event but rather a preliminary melt event to the MMOD, and is excluded from the analysis.

An example of the performance of the winter $T_{\mathrm{B}} \mathrm{D}$ algorithm is shown in Fig. 2 for a case at Pudasjarvi, Finland $\left(65.4^{\circ} \mathrm{N}, 26.97^{\circ} \mathrm{E}\right)$, during the 2013-2014 winter. At Pudasjarvi station, the snow depth first became greater than $0 \mathrm{~cm}$ on day of year (DOY) 291 of 2013. The snow depth was mostly less than $10 \mathrm{~cm}$ for days 291 to 332, with two periods of no snow on the ground while $T_{\max }$ fluctuated around $0^{\circ} \mathrm{C}$. The PMW detected MSOD was on DOY332, corresponding within one week of the date of continuous snow cover above
$10 \mathrm{~cm}$ observed at the station (Fig. 2b). MMOD was detected on DOY64 of 2014; however, there was still snow on the ground until DOY108, typical of high-latitude snow cover where melt onset is followed by the spring thaw, which is a sustained period with high diurnal air temperature variation where the snowpack is melting during the day and refreezing at night. At the end of this melt-refreeze period, the snowpack may be actively melting both day and night until snow disappearance, which can take several weeks (Semmens et al., 2013). During winter 2013-2014, 20 melt days in total were detected at Pudasjarvi, all corresponding to days with $T_{\max } \geq 0{ }^{\circ} \mathrm{C}$. However, not all days with $T_{\max } \geq 0{ }^{\circ} \mathrm{C}$ are detected by PMW as melting, for example DOY $351-352$, for reasons which will be explained further in the validation section.

The winter $T_{\mathrm{B}} \mathrm{D}$ algorithm is applied to time series of $T_{\mathrm{B}}$ for each winter over the period 1988-2013. Melt events may last from one to several days and in some cases the algorithm may split events. For this reason we use the annual number of melt days (rather than number of events) in presenting and analyzing the results. The WPD varies at each pixel and is determined by MSOD and MMOD as described above. This approach is referred to as "PMW-varying" in the following analysis. Since we focus on melt events during the winter period, the $T_{\mathrm{B}} \mathrm{D}$ algorithm is only applied to pixels with MSOD detected before the end of December and with MMOD later than 1 March, i.e., with WPD $>60$ days. The PMW-varying approach is internally consistent in that it takes account of annual variations in winter temperature and snow cover. This is not the case for analysis using a fixed "winter" window where spurious trends can be created from changing seasonality (i.e., earlier snow melt). To highlight this, a fixed window approach is also applied ("PMW-fixed") 


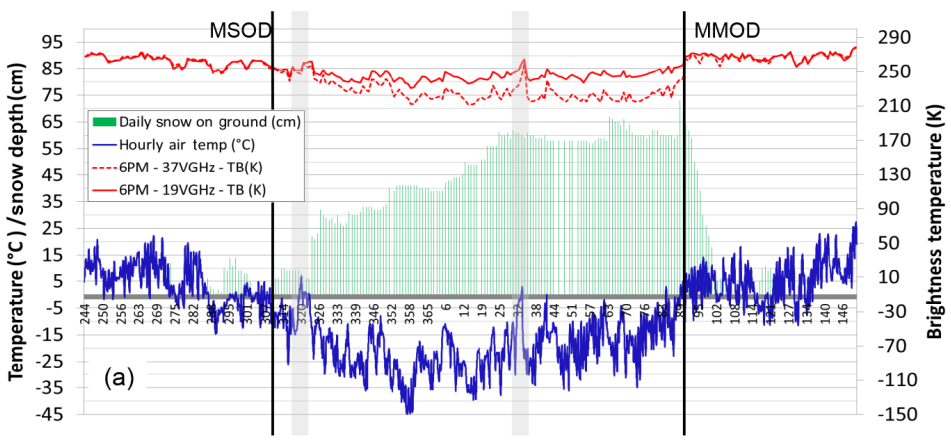

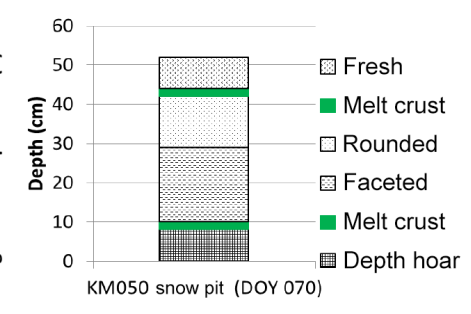

(b)

Figure 3. (a) Time series of hourly air temperature and daily snow depth and $T_{\mathrm{B}}$ at the Thompson, Manitoba Meteorological Station from September 2004 to May 2005; the shaded grey bars highlight the timing of the melt events detected by the PMW satellite data. (b) Snow stratigraphy from the KM050 snow pit site surveyed on DOY097. Note that both the early season and recent melt crusts observed in the snow pit agree reasonably well with the timing of two winter melt events recorded at the Thompson airport and detected by the PMW satellite data.

where the $T_{\mathrm{B}} \mathrm{D}$ algorithm is applied to time series of $T_{\mathrm{B}}$ from November to April. The results presented in the following sections are from the PMW-varying method unless explicitly indicated otherwise. Since the microwave response of melt on permanent snow and ice is different from seasonal terrestrial snow cover, we mask out the Greenland ice sheet and glaciers in our analyses.

\subsection{Winter melt detection for reanalysis datasets}

Winter melt event information from the $0.75^{\circ} \times 0.75^{\circ}$ latitude/longitude European Centre for Medium-Range Weather Forecasts Re-Analysis Interim (ERA-I) (Dee et al., 2011) and the $1 / 2^{\circ}$ latitude by $2 / 3^{\circ}$ longitude Modern EraRetrospective Analysis for Research and Applications (MERRA) (Rienecker et al., 2011) reanalyses were used to evaluate the melt event climatology generated by the PMW method. Melt events in the reanalyses are inferred from 6hourly air temperatures over the same period as the satellite data. For the comparison, a winter thaw event is defined as a period of above-freezing daily mean air temperature occurring during the winter period dominated by below-freezing air temperatures. Here the winter period is defined by $0{ }^{\circ} \mathrm{C}$ crossing dates (between fall and spring) obtained with a centered 30-day moving average of daily mean air temperature, which is analogous to the "PMW-varying" method described above. An additional condition is imposed of a surface snow cover of at least $10 \mathrm{~cm}$ depth for ERA-I and $4 \mathrm{~mm} \mathrm{SWE}$ (snow water equivalent) for MERRA to obtain results comparable to the PMW method of detection over snow-covered ground. The mean daily air temperature is the average of the 00:00, 06:00, 12:00 and 18:00 UTC values. Snow depths for ERA-I are taken from the daily snow depth reconstruction described in Brown and Derksen (2013) to avoid various inconsistencies with the snow depths in the reanalysis.

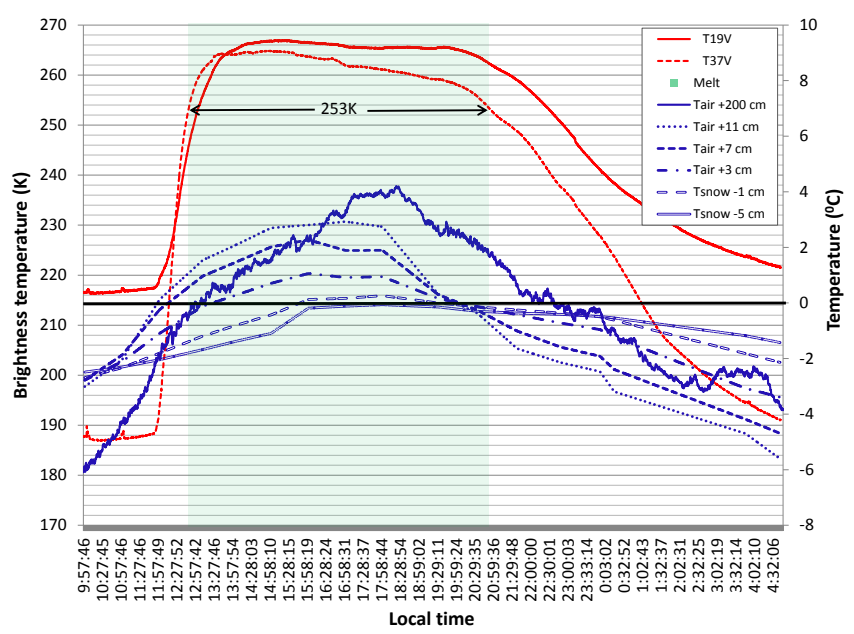

Figure 4. Time series of the surface-based radiometer $T_{\mathrm{B}}$ and the air/snow temperature measurements recorded during 1213 April 2010 at Churchill $\mathrm{MB}\left(58.74^{\circ} \mathrm{N}, 93.82^{\circ} \mathrm{W}\right)$. The green shaded region highlights the period when the winter $T_{\mathrm{B}} \mathrm{D}$ algorithm successfully detected a winter melt event, the onset of which coincides very closely with the $2 \mathrm{~m}$ air temperature sensor.

\subsection{In situ field observations and methods}

The satellite-based winter $T_{\mathrm{B}} \mathrm{D}$ algorithm is validated with surface-based PMW radiometer measurements and nearsurface air/snow temperature observations recorded on 12 13 April 2010 during a field campaign near Churchill, Manitoba, Canada (Derksen et al., 2012). A modified version of the winter $T_{\mathrm{B}} \mathrm{D}$ algorithm is applied to the surface-based radiometer measurements due to the continuous nature of the data. We simply used the average $T_{\mathrm{B}}$ values from the stable pre-melt period as our reference frozen $T_{\mathrm{B}} \mathrm{D}$ value instead of a previous 3-day average.

Furthermore, we try to characterize winter melt events detectable by the winter $T_{\mathrm{B}} \mathrm{D}$ algorithm using snow pit surveys 
recorded during multiple PMW snow measurement campaigns conducted between 2005 and 2010 in both the boreal forest and tundra environments of Canada (Table 2). The number of satellite-detected melt events for the specific EASE-Grid pixels surrounding the snow pit locations are compared to the number of melt forms/ice formations identified within the snowpack. A melt feature identified lower (closer to the ground) is consider an early winter event, while those melt features identified closer to the surface of the snow are considered more recent events. An example of the coincident satellite, air temperature and snow pit information for a survey site near Thompson, Manitoba, is shown in Fig. 3. Hourly air temperatures from weather stations in the vicinity of the snow pits (within $70 \mathrm{~km}$ ) are examined to identify if and when a melt event occurred in the region; how long the melt event lasted; what the average temperature was for the duration of the event and what the minimum, maximum and average $36 \mathrm{~h}$ air temperatures were preceding the melt event. Results of the field evaluation are presented in Sect. 3.1

\subsection{Other data and analysis methods}

Gridded $\left(5^{\circ} \times 5^{\circ}\right)$ monthly surface air temperature over land areas during the study period are obtained from the Climatic Research Unit (University of East Anglia) CRUTem4 dataset (Jones et al., 2012). Seasonal air temperature trends for the fall (September-November), winter (December-February) and spring (March-May) periods are computed to assist the interpretation of trends in winter melt events. The MannKendall method is used for trend analysis taking into account serial correlation following Zhang et al. (2000). Trends are only computed at grid cells with melt events detected in at least 12 winters, and grid cells with trends statistically significant at $90 \%$ level are shown. Correlations between the winter melt-related variables are computed using the Pearson correlation method with significance levels determined from the two-tailed Student's $t$ test.

\section{Results}

\subsection{Field evaluation of the winter $T_{B} D$ algorithm}

Figure 4 illustrates the time series of the surface-based radiometer $T_{\mathrm{B}}$ and air/snow temperature measurements recorded during the 12-13 April melt event near Churchill. The area shaded in green highlights the period for which the modified $T_{\mathrm{B}} \mathrm{D}$ algorithm identified the melt event. As the near-surface air temperatures approached $0{ }^{\circ} \mathrm{C}, T_{\mathrm{B}}$ increased rapidly at both 19 and $37 \mathrm{GHz}$. The detected melt onset occurred $\sim 40 \mathrm{~min}$ after the $11 \mathrm{~cm}$ and $7 \mathrm{~cm}$ air temperatures crossed the $0^{\circ} \mathrm{C}$ threshold and $25 \mathrm{~min}$ before the 2 $\mathrm{m}$ air temperature exceeded $0^{\circ} \mathrm{C}$, likely due to radiant heating from the sun to the snow surface and the boundary layer air temperature probe. The $-1 \mathrm{~cm}$ snow temperature did not reach $0^{\circ} \mathrm{C}$ until $3 \mathrm{~h}$ after the detected melt onset, suggesting that the rapid increases in $T_{\mathrm{B}}$ here were responses to the appearance of liquid water in the snow surface. The influence of radiant heating is evident during the late afternoon/early evening as the incoming solar radiation lessens as the sun begins to set $(\sim 19: 00 \mathrm{LT})$, at which point the snowpack and boundary layer air temperatures all drop below $0{ }^{\circ} \mathrm{C}$, coinciding with a decrease in $T_{\mathrm{B}}$ even while the $2 \mathrm{~m}$ air temperatures are still positive. Compared to the rapid increase in $T_{\mathrm{B}}$ during the melt onset, the more gradual decrease in $T_{\mathrm{B}}$ is likely due to the mixed effects of uneven refreezing of the snow surface and delayed freezing of subsurface liquid water.

The validation results from the seven snow pit survey sites and 12 melt events are summarized in Table 2. The performance of the winter $T_{\mathrm{B}} \mathrm{D}$ algorithm is highlighted in bold for a successful melt detection and in italic for a failed detection. The results suggest that a successful detection is likely when the melt duration lasts for periods longer than $6 \mathrm{~h}$ and/or the melt event has been preceded by warm air temperatures that have warmed the snowpack to near melting conditions (previous day's $T_{\max }>-3^{\circ} \mathrm{C}$ ). In these situations, it is common for melt features to form within the snowpack. The algorithm does not reliably identify short duration melt events or events that occur immediately after extremely cold air/snowpack temperatures (previous $36 \mathrm{~h}$ minimum air temperature $<-13^{\circ} \mathrm{C}$ ). In these instances, the snowpack likely has enough thermal inertia to remain within a frozen state for the whole duration of the melt event, or very quickly return to a frozen state and thus liquid water is not detectable with satellite $T_{\mathrm{B}}$. Out of all 12 melt events investigated, 6 events coincided with observed ROS. Of the six ROS events, half were associated with successful satellite melt detection. Those ROS events that were successfully detected were followed by a continued warming of air temperatures that likely delayed the refreezing of the liquid water in the snow. Those ROS events that were not detected fall under the category of a short-duration melt event as described above.

The winter $T_{\mathrm{B}} \mathrm{D}$ algorithm is very sensitive to liquid water within the snow, but does not necessarily capture all events that can create melt features within the snowpack, largely due to the fact that liquid water from both melt and ROS events tends to re-freeze quickly during the winter months. Unless these events occur very close to the timing of the satellite overpass (ascending $\sim 18: 30 \mathrm{LT}$ and descending 06:30 LT), they may remain undetected. In addition, widespread, spatially expansive melt or ROS events are rare (Bartsch, 2010; Cohen et al., 2015), and as such may be missed by the coarseresolution $(25 \mathrm{~km})$ PMW data. These limitations are common to other melt detection techniques that utilize current spaceborne passive microwave sensors.

\subsection{The spatial distribution of winter melt events}

Figure 5 shows the PMW-derived MSOD, MMOD and WPD during the 1988-2013 period. On average, continuous snow cover starts in the Canadian Arctic islands and high-elevation 


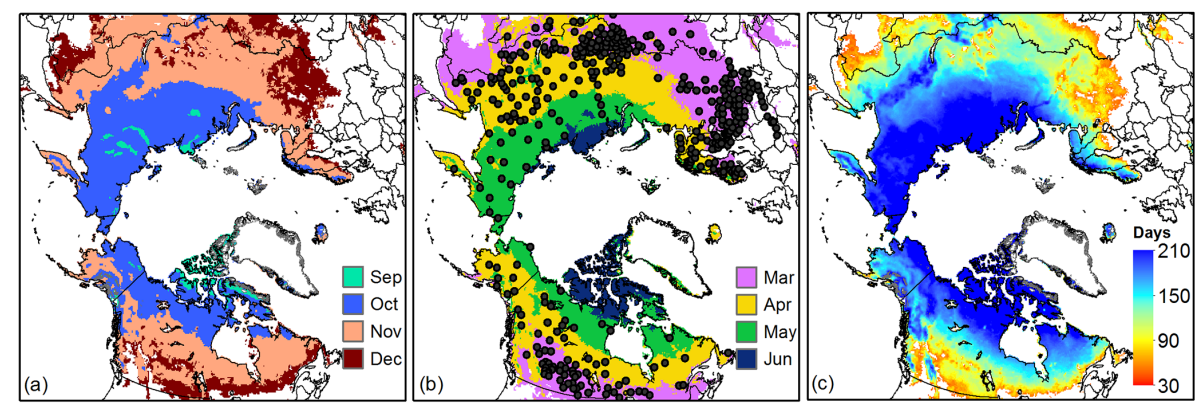

Figure 5. The mean main snow onset date in fall (a), main melt onset date in spring (b), and mean winter period duration (days) (c) during the period 1988-2013. The black dots in (b) represent WMO weather stations used for algorithm development and evaluation.

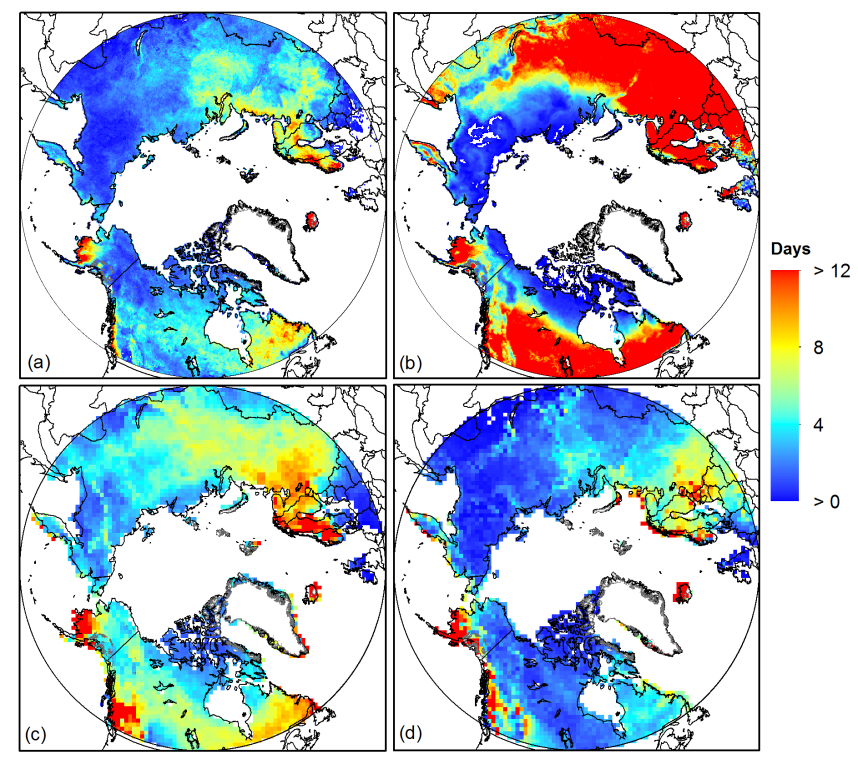

Figure 6. The average annual number of melt days over 19882013 from (a) PMW using a varying winter period; (b) PMW using a fixed winter period (November to April); (c) ERA-Interim; and (d) MERRA.

regions of the Arctic in September and progresses to the open tundra in October (Fig. 5a). By November, most of the areas north of $50^{\circ} \mathrm{N}$ are covered by snow except for some temperate maritime and lower-latitude regions where continuous snow cover sets in December. The spring main melt onset starts at lower latitudes in March, progresses to the boreal forests and tundra in April/May, and reaches the high Arctic in June (Fig. 5b), giving rise to spatial variability in the duration of the winter period from one to seven months on average (Fig. 5c). A pixel-wise definition of winter period for melt detection is required to account for this spatial variability as well as the temporal variability from year-to-year fluctuations in snow cover.

During the 26 winters covered by this study, melt occurred at least once everywhere north of $50^{\circ} \mathrm{N}$ using the PMWvarying window method (Fig. 6a). However, the average cu- mulative number of melt days is less than one week per winter for most areas, with more melt days (around two weeks per winter) occurring in areas with a relatively long snow season and more temperate winter climates (e.g., central Québec and Labrador, southern Alaska and Scandinavia). The spatial distribution patterns of NMD (number of melt days) from ERA-I (Fig. 6c) and MERRA (Fig. 6d) generally agree with that from PMW. However, ERA-I detects about one week more melt days on average in most areas, while MERRA detects fewer melt days in Québec and central Canada relative to PMW. Both ERA-I and MERRA detect more melt days in southern Alaska and western North America (NA). These are relatively deep snowpack regions where melt may not occur in short periods of freezing air temperatures due to the thermal inertia of the snowpack. Compared to the PMW-varying window method (Fig. 6a), there are many more melt days detected using the PMW-fixed window method (Fig. 6b), especially in the relatively temperate climate regions (e.g., northern Europe and lower latitudes of NA and Russia) where the WPD is relatively short and thus limits the possible number of melt days to be detected.

Figure 7 shows the monthly mean NMD from October to June during the period 1988-2013. Winter melt events mainly occur in the fall (October-November) and spring (April-June) months at high latitudes $\left(>60^{\circ} \mathrm{N}\right)$ where continuous snow starts early and melts late (Fig. 5). During November to March for the period 1988-2013, no winter melt events are detected across large areas of Siberia and the Canadian and Alaskan tundra where the monthly surface air temperature is usually lower than $-20^{\circ} \mathrm{C}$ (not shown). On average, April has the maximum extent and duration of winter melt events (Fig. 7).

\subsection{Changes in snow cover and winter melt events}

The PMW-derived estimates of changes in snow cover (MSOD, MMOD and WPD) over the 1983-2013 period are shown in Fig. 8. Large regions of the Arctic exhibit trends toward later snow onset, particularly over northern Scandinavia, western Russia, Alaska and Québec (Fig. 8a, d). The timing of the spring main melt onset date exhibits trends to 


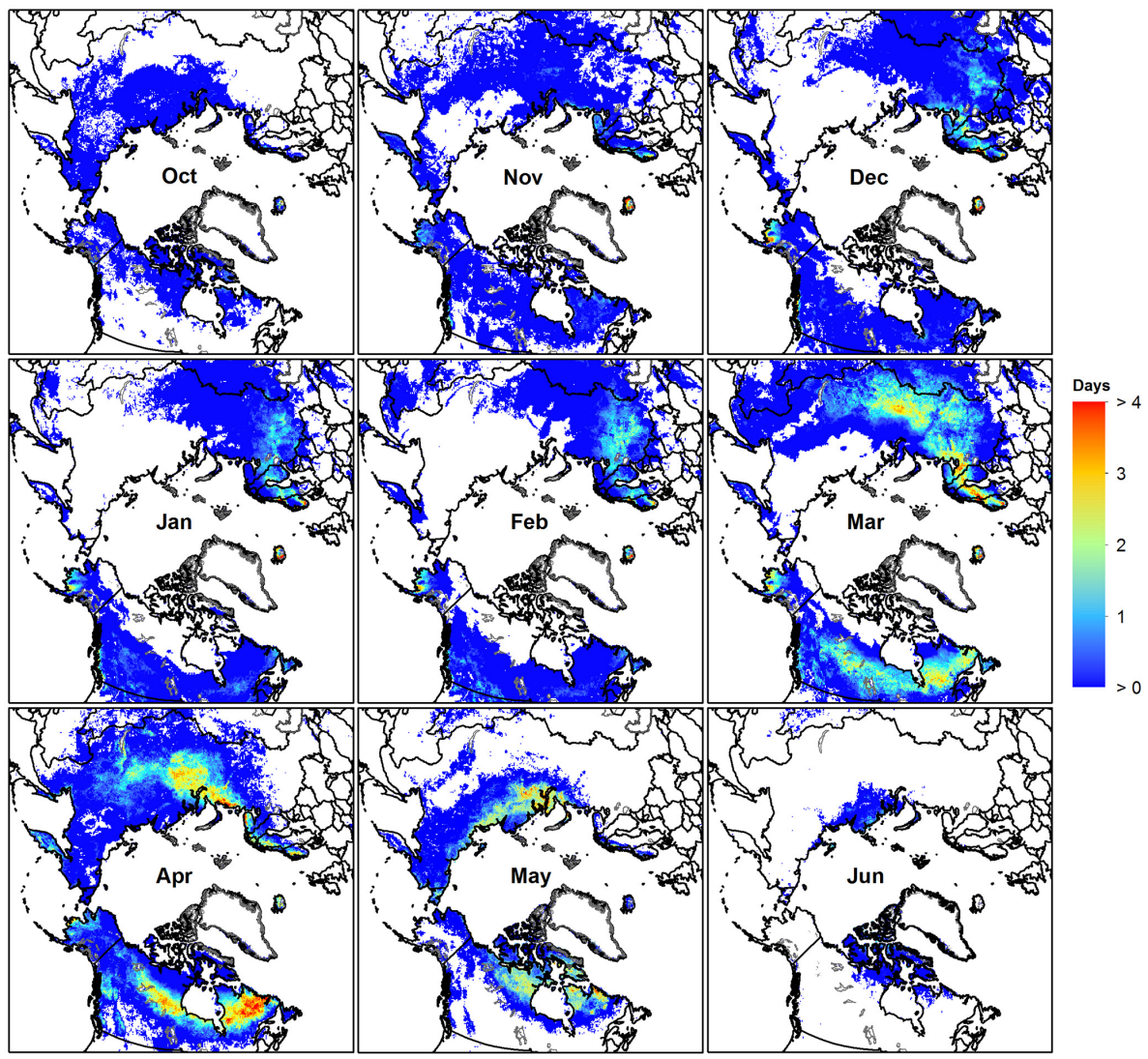

Figure 7. Monthly mean number of melting days from PMW during the period 1988-2013.

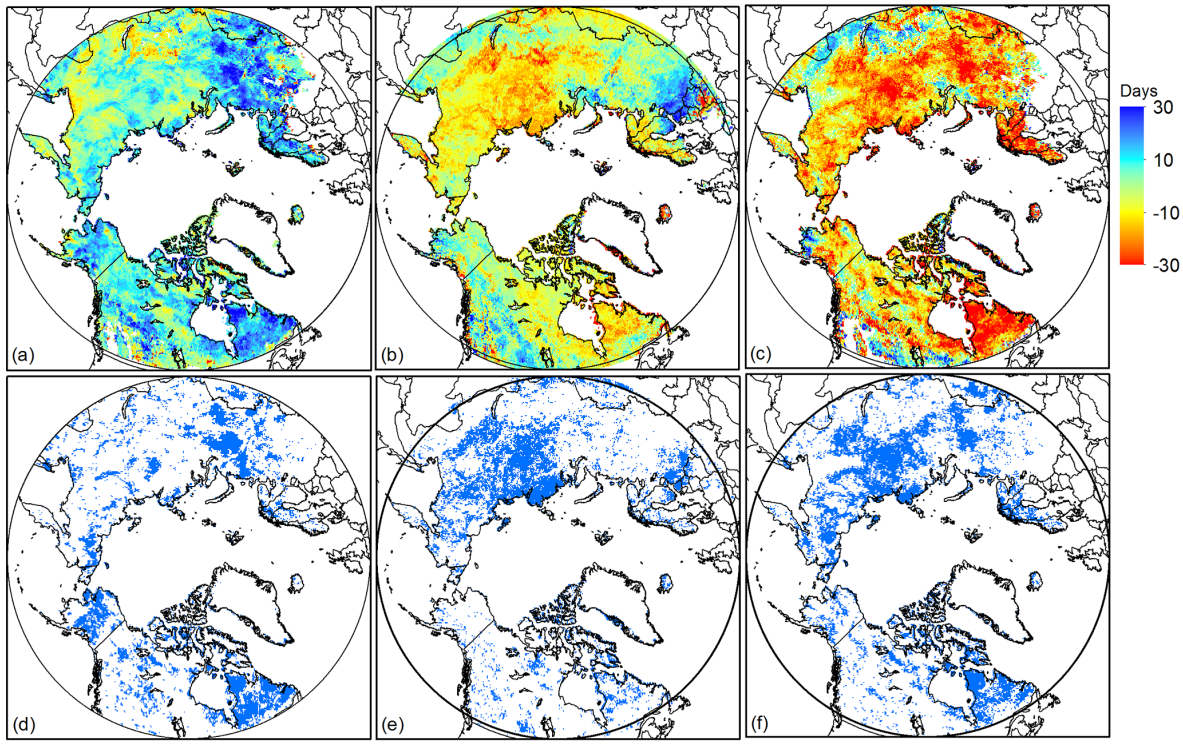

Figure 8. Mann-Kendall trends (days/26 years) over the period 1988-2013 in (a) MSOD, (b) MMOD, (c) WPD. Grid cells with trends statistically significant at the $90 \%$ level are shown in (d) MSOD, (e) MMOD, and (f)WPD.

earlier melt over most of the Arctic except for northern Europe and western NA (Fig. 8b, e). The net effect is significant negative trends in winter duration period that exceed
-10 days decade ${ }^{-1}$ over large regions of the Arctic (Fig. 8c, f). 

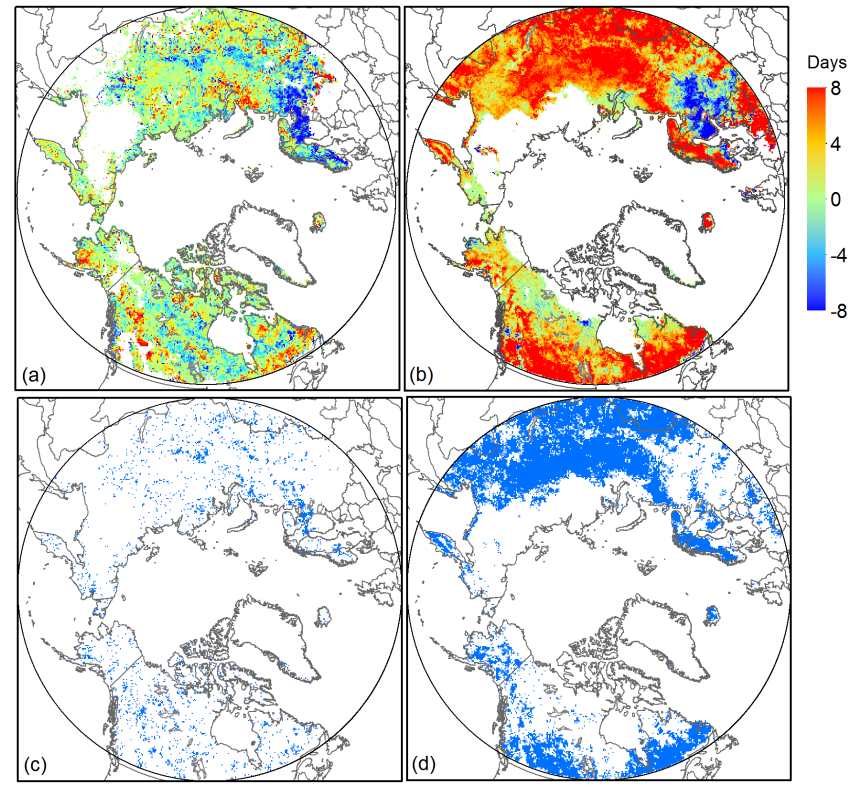

Figure 9. Mann-Kendall trends (days/26 years) over the period 1988-2013 in the number of winter melt days from (a) PMW; (b) PMW-fixed; (c) and (d) show grid cells with trends statistically significant at the $90 \%$ level in (a) and (b) respectively.

Over the study period, there are few significant trends in NMD over the Arctic (Fig. 9a, c), and where there are significant trends, these are dominated by decreases over northern Europe. The spatial distribution patterns of NMD trends contrast markedly between the PMW-varying and the PMWfixed results (Fig. 9b, d). Trends from PMW-fixed are dominated by increasing trends in NMD over most of the Arctic except for northern Europe. Corresponding trends from the reanalyses are not shown because the annual winter thaw frequency series from ERA-I and MERRA are not always consistent over the 1988-2013 period in some regions. For example over northern Québec (not shown) the two series are well correlated over the period from 1980 to 2001 ( $r=0.75$, $p<0.001$ ) but diverge markedly after 2001, when numerous changes in data assimilation streams occurred in both reanalysis datasets (Rapaic et al., 2015). This underscores the advantage of the PMW melt detection approach, which is based on a consistent $T_{\mathrm{B}}$ time series.

\section{Discussion and conclusions}

An algorithm for detecting terrestrial winter melt events using satellite PMW measurements is developed and evaluated using in situ observations at weather stations and field surveys. The winter $T_{\mathrm{B}} \mathrm{D}$ algorithm is able to successfully detect winter melt events lasting for more than $6 \mathrm{~h}$ in different environments but is less successful for short duration melt and ROS events due to the thermal inertia of the snowpack and/or the overpass and resolution limitation of the PMW

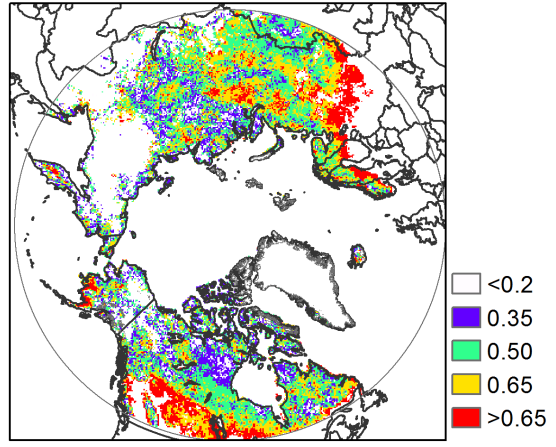

Figure 10. The correlation coefficient between number of melt days and the duration of winter period from PMW during 1988-2013. Correlations greater than 0.35 are statistically significant at $90 \%$ confidence level.

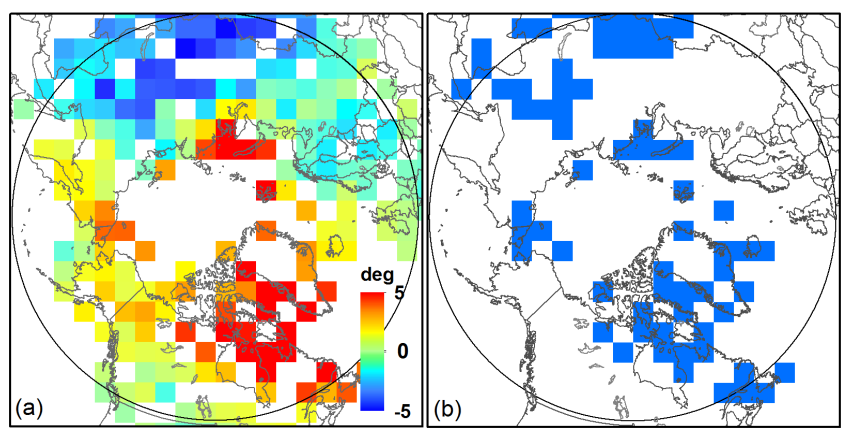

Figure 11. (a) Surface air temperature trends $\left({ }^{\circ} \mathrm{C} / 26\right.$ years) during the winter season (DJF) for north of $50^{\circ} \mathrm{N}$ land areas from CRUTem4 over the period 1988-2013, (b) grid cells with trends statistically significant at the $90 \%$ level in (a).

data. The algorithm should also be able to detect subsurface melt events although this aspect is not evaluated in this paper. Similar channel difference approaches have also been used for melt onset detection over the Arctic sea ice (e.g., Drobot and Anderson, 2001). However, the emissivities of first-year sea ice are different than that of multi-year sea ice, and the emissivities over multi-year sea ice can have a large range due to the varied histories of the ice floes. These complicate the detection of melt over sea ice, so we do not recommend the use of the algorithm developed in this study for melt detection over sea ice. A multiple indicators approach was developed in Markus et al. (2009) for melt-refreeze detection over the Arctic sea ice.

During the period 1988-2013, winter melt occurred at least once everywhere north of $50^{\circ} \mathrm{N}$. The average cumulative melt days totaled less than one week per winter for most Arctic areas, with more melt days (approximately two weeks per winter) occurring in areas with relatively long snow season and temperate climate. Winter melt events are not detected in some areas of Siberia and the Canadian and Alaskan tundra where the monthly surface air temperature is usually 


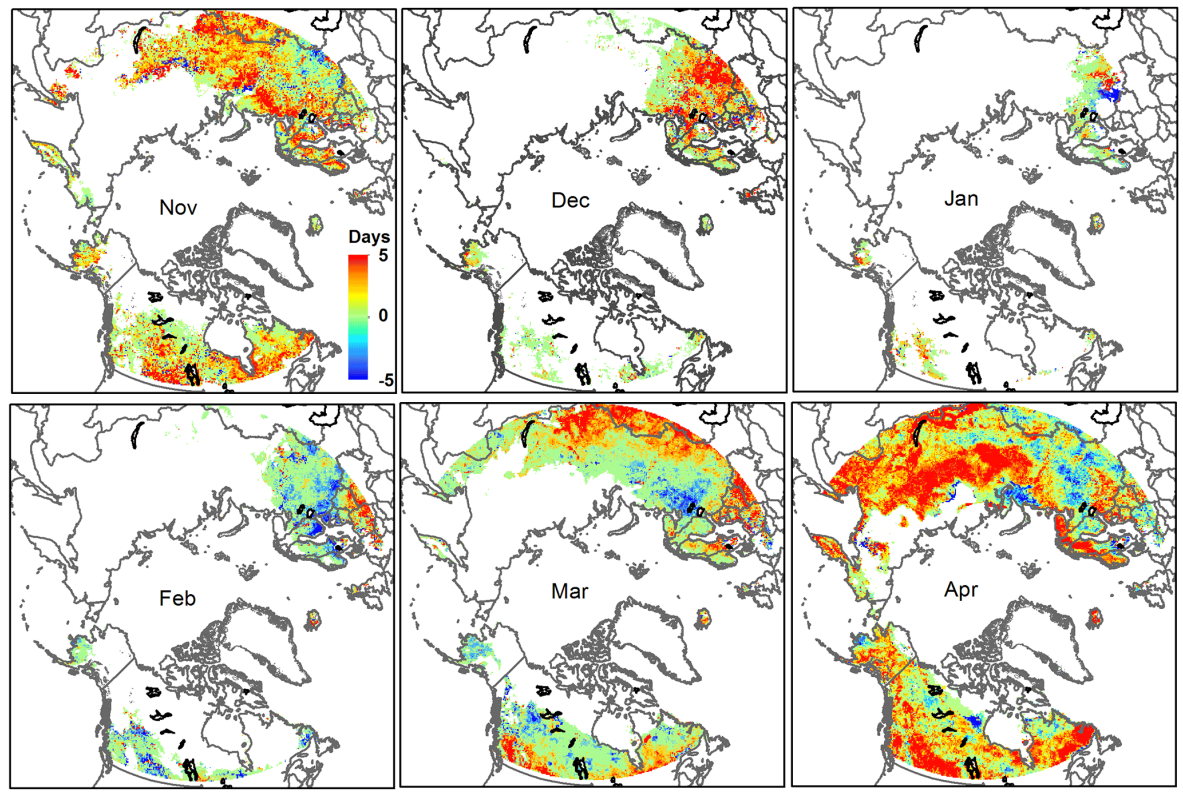

Figure 12. Mann-Kendall trends (days/26 years) in the number of melt days derived by PMW-fixed from November to April during the period 1988-2013.

lower than $-20^{\circ} \mathrm{C}$. The spatial distribution patterns of NMD are in general consistent with results inferred from surface air temperature data in the reanalysis datasets (ERA-I and MERRA) and PMW, and also with the spatial patterns of refreeze events derived from QuikSCAT for north of $60^{\circ} \mathrm{N}$ (Bartsch, 2010; Bartsch et al., 2010).

Over the period 1988-2013, large regions of the Arctic exhibit trends toward later snow onset in fall and earlier melt onset in spring, resulting in significant negative trends in winter period duration. The number of melt days was observed to be significantly positively correlated with the duration of winter period over most of the Arctic, particularly in regions where interannual variability in snow cover is higher (Fig. 10). However, there are few areas of the Arctic with locally significant trends in NMD except for northern Europe, where there is evidence of significant negative NMD trends consistent with the positive correlations between WPD and NMD over this area (as shown in Fig. 10). The lack of significant trends in winter melt events observed in this study is considered to be related to the relatively short period of data available for analysis and the dynamic mechanisms generating winter melt and ROS events that produce more random and chaotic environmental response patterns (Trenberth et al., 2015; Cohen et al., 2015). This is underscored by trend analysis of annual numbers of winter melt events in ERA-I and MERRA over a longer 1980-2014 period (not shown) where locally significant increasing trends were only observed at $1 \%$ of snowcovered land points in MERRA and 2\% in ERA-I. Cohen et al. (2015) also found that the frequency of ROS events was correlated to large-scale modes of atmospheric circu- lation that contributes to regional-scale variability in ROS trends. The absence of positive winter melt trends observed in this study may also be linked to the seasonal pattern of warming over Arctic land areas during 1988-2013, which is dominated by warming in the snow cover onset fall period (trend $=0.67^{\circ} \mathrm{C}$ decade $^{-1}, \quad p<0.001$ ) with comparatively little warming in the winter (trend $=-0.15^{\circ} \mathrm{Cdecade}^{-1}$, $p=0.47$ ) and spring (trend $=0.20^{\circ} \mathrm{Cdecade}^{-1}, p=0.22$ ) period. The spatial character of winter warming over the period (Fig. 11) also shows little warming or cooling over the regions experiencing the largest NMD frequencies. This conclusion is consistent with the findings of Cohen et al. (2012).

There is field evidence of changes in snowpack density and ice layers from a number of locations in the Arctic that is supported by an increased frequency of winter thaw events (Chen et al., 2013; Groisman et al., 2003; McBean et al., 2005; Johansson et al., 2011). However, winter thaw events in some of these studies were inferred from air temperature observations (Groisman et al., 2003; McBean et al., 2005), which are different from results detected by PMW measurements.

As previously pointed out in Fig. 9b, the frequency of winter melt events is strongly influenced by the method used to define WPD. A spatially and temporally varying definition of WPD is required as the use of a fixed window generates artificial NMD trends from changes in the timing of the snow cover season. This is further demonstrated in Fig. 12, where monthly NMD trends are computed using a fixed WPD of November-April. The results clearly demonstrate that increases in NMD are being driven by trends during the snow cover shoulder seasons of November-December and March- 
April and not the main winter period. A number of studies reporting increasing NMD trends used fixed winter periods in their analyses (e.g., Groisman et al., 2003; McBean et al., 2005).

The major advantage of the PMW winter melt event method presented here is that it is based on physical processes in the snowpack (melt-refreeze), unlike thaw events inferred from air temperature observations that may or may not be associated with snowpack melt processes depending on the thermal inertia of the snowpack. The PMW series is also consistent over time unlike some reanalysis datasets. Several studies have focused on the development of ROS detection methods using PMW data and encouraging results were obtained at some field sites (e.g., Dolant et al., 2016; Grenfell and Putkonen, 2008; Langlois et al., 2016). Future work will focus on the detection of pan-Arctic ice lenses (from both melt-refreeze and ROS events) by integrating PMW techniques. Additional work is also needed to evaluate the performance of the winter melt algorithm in areas with deep snow and complex terrain where the range in $T_{\mathrm{B}} \mathrm{D}$ for dry snow vs. wet snow is likely to be much smaller (Tong et al., 2010).

\section{Data availability}

PMW: Armstrong, R. L., Knowles, K. W., Brodzik, M. J., and Hardman, M. A.: http://nsidc.org/data/NSIDC-0032.

ERA-Interim: Dee, D. P., Uppala, S. M., Simmons, A. J., Berrisford, P., Poli, P., Kobayashi, S., Vitart, F., http://apps. ecmwf.int/datasets/data/interim-full-daily/levtype $=$ sfc/.

MERRA: Rienecker, M. M., Suarez, M. J., Gelaro, R., Todling, R., Bacmeister, J., Liu, E., Bosilovich, M. G., Schubert, S. G., Takacs, L., Kim, G.-K., Bloom, S., Chen, J., Collins, D., Conaty, A., Silva, A., Gu, W., Joiner, J., Koster, R. D., Lucchesi, R., Molod, A., Owens, T., Pawson, S., Pegion, P., Redder, C. R., Reichle, R., Robertson, F. R., Ruddick, A. G., Sienkiewicz, M., and Woollen, J.: https: //climatedataguide.ucar.edu/climate-data/nasa-merra.

Weather Station Data Global Surface Summary of the Day dataset archived at the National Climate Data Center https://data.noaa.gov/dataset/ global-surface-summary-of-the-day-gsod.

CRUTem4: Jones, P. D., Lister, D. H., Osborn, T. J., Harpham, C., Salmon, M. and Morice, C. P.: http://www. metoffice.gov.uk/hadobs/crutem4/.

Surface-based Radiometer: it will be published in Environment Canada Data Catalogue, http://donnees-data.intranet. ec.gc.ca/geonetwork/home/eng.

If readers want a copy of the data before it is published, please contact the authors. The snow pit data used in the paper are included in Table 2 .
Acknowledgements. The in situ snow survey data used in this study are the result of multiple campaigns carried out over many years and supported by numerous organizations who have provided direct funding or logistical support, or contributed people in the field. There are too many individuals involved to list here, but we would like to acknowledge the institutions and funding sources that contributed to this effort: Environment and Climate Change Canada, the Canadian Space Agency, University of Waterloo, Université de Sherbrooke, Wilfrid Laurier University, the Churchill Northern Study Centre, the Aurora Research Institute, the Canadian Foundation for Climate and Atmospheric Science, Manitoba Hydro, the Northwest Territories Power Corporation and Indian and Northern Affairs Canada. The following data centers are acknowledged for providing data: The National Snow and Ice Data Center for passive microwave satellite data, the National Climate Data Center for the Global Summary of the Day dataset, the Climatic Research Unit - University of East Anglia for the CRUtem4v gridded air temperature data, the European Centre for Medium-Range Weather Forecasts (ECMWF) for the ERA-Interim data, and the Global Modeling and Assimilation Office (GMAO) at NASA Goddard Space Flight Center for MERRA data. The authors would like to thank Anne Walker for providing helpful comments regarding an early version of the manuscript. Helpful comments from three anonymous referees are gratefully acknowledged.

Edited by: C. Duguay

Reviewed by: three anonymous referees

\section{References}

Abdalati, W., Steffen, K., Otto, C., and Jezek, K. C.: Comparison of brightness temperatures from SSM/I instruments on the DMSP F8 and F11 satellites for Antarctica and the Greenland ice sheet, Int. J. Remote Sens., 16, 1223-1229, doi:10.1080/01431169508954473, 1995.

AMAP: Snow, Water, Ice and Permafrost in the Arctic (SWIPA): Climate Change and the Cryosphere, Arctic Monitoring and Assessment Programme (AMAP), Oslo, Norway, xii + 538 pp., 2011.

Armstrong, R. L., Knowles, K. W., Brodzik, M. J., and Hardman, M. A.: DMSP SSM/I Pathfinder Daily EASE-Grid Brightness Temperatures, Version 2, (1988-2013), Boulder, Colorado, USA, National Snow and Ice Data Center, 10.5067/3EX2U1DV3434, 1994.

Bartsch, A.: Ten Years of SeaWinds on QuikSCAT for Snow Applications, Remote Sens., 2, 1142-1156, doi:10.3390/rs2041142, 2010.

Bartsch, A., Kumpula, T., Forbes, B. C., and Stammler, F.: Detection of snow surface thawing and refreezing in the Eurasian Arctic with QuikSCAT: implications for reindeer herding, Ecol. Appl., 20, 2346-2358, 2010.

Bokhorst, S. F., Bjerke, J. W., Tømmervik, H., Callaghan, T. V, and Phoenix, G. K.: Winter warming events damage sub-Arctic vegetation: Consistent evidence from an experimental manipulation and a natural event, J. Ecol., 97, 1408-1415, 2009.

Boon, S., Sharp, M., and Nienow, P.: Impact of an extreme melt event on the runoff and hydrology of a high Arctic glacier, Hydrol. Process., 17, 1051-1072, doi:10.1002/hyp.1194, 2003. 
Brown, R. D. and Robinson, D. A.: Northern Hemisphere spring snow cover variability and change over 1922-2010 including an assessment of uncertainty, The Cryosphere, 5, 219-229, doi:10.5194/tc-5-219-2011, 2011.

Brown, R. D. and Derksen, C.: Is Eurasian October snow cover extent increasing?, Environ. Res. Lett., 8, 024006, doi:10.1088/1748-9326/8/2/024006, 2013.

Bulygina, O. N., Groisman, P. Y., Razuvaev, V. N., and Radionov, V. F.: Snow cover basal ice layer changes over Northern Eurasia since 1966, Environ. Res. Lett., 5, 015004, doi:10.1088/17489326/5/1/015004, 2010.

Callaghan, T. V., Johansson, M., Brown, R. D., Groisman, P. Y., Labba, N., Radionov, V., Barry, R. G., Bulygina, O. N., Essery, R. L., Frolov, D. M., and Golubev, V. N.: The changing face of Arctic snow cover: A synthesis of observed and projected changes, Ambio, 40, 17-31, 2011.

Cavalieri, D. J., Parkinson, C., DiGirolamo, N., and Ivanoff, A.: Intersensor Calibration Between F13 SSMI and F17 SSMIS for Global Sea Ice Data Records, NASA technical report, 13 pp., 2012

Chang, A., Foster, J., and Hall, D.: Nimbus-7 SMMR derived global snow cover parameters, Ann. Glaciol., 9, 39-44, 1987.

Chen, W., Russell, D. E., Gunn, A., Croft, B., Chen, W. R., Fernandes, R., Zhao H., Li, J., Zhang, Y., Koehler, K., Olthof, I., Fraser, R. H., Leblanc, S. G., Henry, G. R., White, R. G., and Finstad, G. L.: Monitoring habitat condition changes during winter and pre-calving migration for Bathurst Caribou in northern Canada, Biodivers., 14, 36-44, 2013.

Cohen, J., Furtado, J., Barlow, M., Alexeev, V., and Cherry, J.: Asymmetric seasonal temperature trends, Geophys. Res. Lett., 39, L04705, doi:10.1029/2011GL050582, 2012.

Cohen, J., Ye, H., and Jones, J.: Trends and variability in rain-onsnow events, Geophys. Res. Lett., 42, 7115-7122, 2015.

Dee, D. P., Uppala, S. M., Simmons, A. J., Berrisford, P., Poli, P., Kobayashi, S., and Vitart, F.: The ERA-Interim reanalysis: Configuration and performance of the data assimilation system, Q. J. Roy. Meteor. Soc., 137, 553-597, doi:10.1002/qj.828, 2011.

Derksen, C. and Brown, R.: Spring snow cover extent reductions in the 2008-2012 period exceeding climate model projections, Geophys. Res. Lett., 39, L19504, doi:10.1029/2012GL053387, 2012.

Derksen, C., Sturm, M., Liston, G., Holmgren, J., Huntington, H., Silis, A., and Solie, D.: Northwest Territories and Nunavut snow characteristics from a sub-Arctic traverse: Implications for passive microwave remote sensing, J. Hydrometeorol., 10, 448-463, 2009.

Derksen, C., Toose, P., Lemmetyinen, J., Pulliainen, J., Langlois, A., Rutter, N., and Fuller, M. C.: Evaluation of passive microwave brightness temperature simulations and snow water equivalent retrievals through a winter season, Remote Sens. Environ., 117, 236-248, 2012.

Derksen, C., Lemmetyinen, J., Toose, P., Silis, A., Pulliainen, J., and Sturm, M.: Physical properties of Arctic versus subarctic snow: Implications for high latitude passive microwave snow water equivalent retrievals, J. Geophys. Res., 119, 7254-7270, doi:10.1002/2013JD021264, 2014.

Dolant, C., Langlois, A., Montpetit, B., Brucker, L., Roy, A., and Royer, A.: Development of a rain-on-snow detection algorithm using passive microwave radiometry, Hydrol. Process., 30, 3184 3196. doi:10.1002/hyp.10828, 2016.

Drobot, S. D. and Anderson, M. R.: An improved method for determining snowmelt onset dates over Arctic sea ice using scanning multichannel microwave radiometer and Special Sensor Microwave/Imager data, J. Geophys. Res., 106, 24033-24049, doi:10.1029/2000JD000171, 2001.

Grenfell, T. C. and Putkonen, J.: A method for the detection of the severe rain-on-snow event on Banks Island, October 2003, using passive microwave remote sensing, Water Resour. Res., 44 W03425, doi:10.1029/2007WR005929, 2008.

Groisman, P. Y., Sun, B., Vose, R. S., Lawrimore, J. H., Whitfield, P. H., Førland, E., Hanssen-Bauer, I., Serreze, M. C., Razuvaev, V. N., and Alekseev, G. V.: Contemporary climate changes in high latitudes of the Northern Hemisphere: daily time resolution, Proc. 14th AMS Symp. on Global Change and Climate, 1-10, Long Beach, CA, 2003.

Hansen, B. B., Aanes, R., Herfindal, I., Kohler, J., and Saether, B. E.: Climate, icing, and wild arctic reindeer: past relationships and future prospects, Ecology, 92, 1917-1923, 2011.

Hay, L. E. and McCabe, G. J.: Hydrologic effects of climate change in the Yukon River Basin, Clim. Chang., 100, 509-523, 2010.

Johansson, C., Pohjola, V. A., Jonasson, C., and Callaghan, T. V.: Multi-decadal changes in snow characteristics in sub-Arctic Sweden, Ambio, 40, 566-574, 2011.

Jones, P. D., Lister, D. H., Osborn, T. J., Harpham, C., Salmon, M., and Morice, C. P.: Hemispheric and large-scale land surface air temperature variations: an extensive revision and an update to 2010, J. Geophys. Res., 117, D05127, doi:10.1029/2011JD017139, 2012.

Kim, Y., Kimball, J. S., McDonald, K. C., and Glassy, J.: Developing a global data record of daily landscape freeze/thaw status using satellite passive microwave remote sensing, IEEE Trans. Geosci. Remote Sens., 49, 949-960, doi:10.1109/TGRS.2010.2070515, 2011.

Langlois, A., Royer, A., Derksen, C., Montpetit, B., Dupont, F., and Goïta K.: Coupling the snow thermodynamic model SNOWPACK with the microwave emission model of layered snowpacks for subarctic and arctic snow water equivalent retrievals, Water Resour. Res., 48, W12524, doi:10.1029/2012WR012133, 2012.

Langlois, A., Johnson, C. A., Montpetit, B., Royer, A., BlukaczRichards, E. A., Neave, E., Dolant, C., Roy, A., Arhonditsis, G., Kim, D.-K. F., Kaluskar, S., and Brucker, L.: Detection of rainon-snow (ROS) events and ice layer formation using passive microwave radiometry: A context for Peary caribou habitat in the Canadian Arctic, Remote Sens. Environ., in review, 2016.

Liston, G. E. and Hiemstra, C. A.: The Changing Cryosphere: PanArctic Snow Trends (1979-2009), J. Climate, 24, 5691-5712, doi:10.1175/JCLI-D-11-00081.1, 2011.

Markus, T., Stroeve, J. C., and Miller, J.: Recent changes in Arctic sea ice melt onset, freeze-up, and melt season length, J. Geophys. Res., 114, C12024, doi:10.1029/2009JC005436, 2009.

McBean, G., Alexeev, G., Chen, D., Førland, E., Fyfe, J., Groisman, P. Y., King, R., Melling, H., Vose, R., and Whitfield, P. H.: Arctic climate: past and present, Arctic Climate Impact Assessment, Cambridge, Cambridge University Press, 2, 21-60, 2005.

Nghiem, S. V., D. K. Hall, T. L. Mote, M. Tedesco, M. R. Albert, K. Keegan, C. A. Shuman, N. E. DiGirolamo, and G. Neumann: The 
extreme melt across the Greenland ice sheet in 2012, Geophys. Res. Lett., 39, L20502, doi:10.1029/2012GL053611, 2012.

Pedersen, S. H., Liston, G. E., Tamstorf, M. P., WestergaardNielsen, A., and Schmidt, N. M.: Quantifying Episodic Snowmelt Events in Arctic Ecosystems, Ecosystems, 1-18, 2015.

Rapaic, M., Brown, R., Markovic, M., and Chaumont, D.: An evaluation of temperature and precipitation surface-based and reanalysis datasets for the Canadian Arctic, 1950-2010, Atmos. Ocean., 53, 283-303, doi:10.1080/07055900.2015.1045825, 2015.

Rees, A., Lemmetyinen, J., Derksen, C., Pulliainen, J., and English, M.: Observed and modeled effects of ice lens formation on passive microwave brightness temperatures over snow covered tundra, Remote Sens. Environ., 114, 116-26, 2010.

Rennert, K. J., Roe, G., Putkonen, J., and Bitz, C. M.: Soil thermal and ecological impacts of rain on snow events in the circumpolar Arctic, J. Climate, 22, 2302-2315, 2009.

Rienecker, M. M., Suarez, M. J., Gelaro, R., Todling, R., Bacmeister, J., Liu, E., Bosilovich, M. G., Schubert, S. G., Takacs, L., Kim, G.-K., Bloom, S., Chen, J., Collins, D., Conaty, A., Silva, A., Gu, W., Joiner, J., Koster, R. D., Lucchesi, R., Molod, A., Owens, T., Pawson, S., Pegion, P., Redder, C. R., Reichle, R., Robertson, F. R., Ruddick, A. G., Sienkiewicz, M., and Woollen, J.: MERRA: NASA's Modern-Era Retrospective Analysis for Research and Applications, J. Climate, 24, 3624-3648, doi:10.1175/JCLI-D-11-00015.1, 2011.

Semmens, K. A., Ramage, J., Bartsch, A., and Liston, G. E.: Early snowmelt events: detection, distribution, and significance in a major sub-arctic watershed, Environ. Res. Lett., 8, 1-11, doi:10.1088/1748-9326/8/1/014020, 2013.

Stroeve, J., Maslanik, J., and Li, X.: An intercomparison of DMSP F11- and F13-derived sea ice products, Remote Sens. Environ., 64, 132-152, doi:10.1016/S0034-4257(97)00174-0, 1998.
Tedesco, M.: Snowmelt detection over the Greenland ice sheet from SSM/I brightness temperature daily variations, Geophys. Res. Lett., 34, L02504, doi:10.1029/2006GL028466, 2007.

Tong, J., Dery, S., Jackson, P., and Derksen, C.: Testing snow water equivalent retrieval algorithms for passive microwave remote sensing in an alpine watershed of western Canada, Can. J. Remote Sens., 36, 74-86, 2010.

Trenberth, K. E., Fasullo, J. T., and Shepherd, T. G.: Attribution of climate extreme events, Nat. Clim. Chang., 5, 725-730, doi:10.1038/nclimate2657, 2015.

Wang, L., Wolken, G., Sharp, M., Howell, S., Derksen, C., Brown, R., Markus, T., and Cole, J.: Integrated pan-Arctic melt onset detection from satellite active/passive microwave measurements, 2000-2009, J. Geophys. Res., 116, D22103, doi:10.1029/2011JD016256, 2011.

Wang, L., Derksen, C., and Brown, R., and Markus, T.: Recent changes in pan-Arctic melt onset from satellite passive microwave measurements, Geophys. Res. Lett., 40, 522-528, doi:10.1002/grl.50098, 2013.

Wilson, R. R., Bartsch, A., Joly, K., Reynolds, J. H., Orlando, A., and Loya, W. M.: Frequency, timing, extent, and size of winter thaw-refreeze events in Alaska 2001-2008 detected by remotely sensed microwave backscatter data, Polar Biol., 36, 419-426, doi:10.1007/s00300-012-1272-6, 2013.

Ulaby, F., Moore, R., and Fung, A.: Microwave Remote Sensing: Active and Passive, Vol. 2, Norwood, Massachusetts, Artech House, 816-920, 1986.

Zhang, X., Vincent, L. A., Hogg, W. D., and Niitsoo, A.: Temperature and precipitation trends in Canada during the 20th century, Atmos. Ocean., 38, 395-429, doi:10.1080/07055900.2000.9649654, 2000. 